\title{
Cinema and its ability to represent a staged reality
}

\author{
Carlos Ruiz Carmona*
}

Resumo: O artigo é uma reflexão sobre a relação entre o discurso cinematográfico e a realidade discutindo as restrições técnicas e as potencialidades criativas para representar uma impresão de realidade. $\mathrm{O}$ artigo emerge do pressuposto que as qualidades técnicas do cinema apenas representam uma aparência técnica da realidade que deve satisfazer certas expectativas culturais.

Palavras-chave: documentário; representar a realidade; narrative; aparência técnica.

Resumen: Este artículo es una reflexión sobre la relación entre el discurso y la realidad cinematográfica, y discute las limitaciones técnicas y el potencial creativo para representar una impresión de realidad. El artículo surge del presupuesto de que las cualidades técnicas del cine representan tan sólo una apariencia técnica de la realidad que debe satisfacer ciertas expectativas culturales.

Palabras clave: documental; representar la realidad; narrativa; apariencia técnica.

\begin{abstract}
This article is a reflection on the relationship between cinematographic discourse and reality: discussing cinema's technical restrictions and creative possibilities to represent an impression of reality. This article emerges from the assumption that cinema's technical qualities can only represent a technical appearance of reality which must satisfy certain cultural expectations.

Keywords: documentary; representing reality; narrative; technical appearance.

Résumé: Cet article est une réflexion sur la relation entre le discours et la réalité cinématographique : il s'agit de discuter des contraintes techniques et du potentiel créatif pour produire une impression de réalité. Cet article dérive de l'hypothèse selon laquelle les qualités techniques du film ne représentent qu'une apparence technique de la réalité qui doit satisfaire certaines attentes culturelles.

Mots-clés: documentaire; représentent la réalité; le récit; l'aspect technique.
\end{abstract}

* Portuguese Catholic University, School of Arts, Department of Cinema and Audiovisual, Centre for Research in Science and Technology of the Arts - CITAR. 4169-005, Porto, Portugal. E-mail: carlosruizcarmona@gmail.com

Submission of the article: december 30th, 2015. Notification of acceptance: february 22th, 2016.

Doc On-line, n. 19, março de 2016, www.doc.ubi.pt, pp. 201-212. 
Paris, 1895. The Lumière brothers present to the world a magical invention, a perfect combination of lightweight portable camera and projector. This new invention was capable of representing one of the most essential features of the visible world that we inhabit: movement. From that very moment cinema appeared to be directly associated with the notion of reality (Barnouw, 1993: 7; Barsam, 1992: 20-21).

In $1897,{ }^{1}$ during the projection of a one minute film, L'arrivée d'un train à la Ciotat, a train approaches growing bigger in size on the cinema screen. The spectators screamed in horror and dodged to avoid "being run over by the train coming towards them" - a very different experience from Edison's theatre Studio Vaudeville performances. The astonished audience felt it was a "real-life" experience: reality in movement as they normally experienced it through their own senses. It took only one year for the magical invention to spread throughout the world. After one of Lumière's popular sessions Maxim Gorky wrote about his experience: "It is a world without sound, without colour. Everything there - the earth, the trees, the people, the water and the air - is dipped in monotonous grey". Gorky continues:

Noiselessly, the locomotive disappears beyond the edge of the screen. The train comes to a stop, and grey figures silently emerge from the cars, soundlessly greet their friends, laugh, walk, run, bustle, and ... are gone. And here is another picture. Three men seated at the table, playing cards, their faces are tense, their hands move swiftly, the cupidity of the players is betrayed by the trembling fingers and by the twitching of their facial muscles. They play ..... Suddenly, they break .. into laughter, and the waiter who has stopped at their table with beer laughs too. They laugh until their sides split but not a sound is heard. It seems as if these people have died and their shadows have been condemned to play cards in silence unto eternity ... (Gorki, 1996: 6-8).

Gorky's poignant description of his experience raises one essential question: how is it possible that a soundless grey two dimensional image provided a real experience of a colourful sonic three dimensional world? Especially if we consider that, at the time, audiences had none or little experience of watching cinema. According to David Bordwell perceiving and interpreting cinematic images is a learned activity that requires a wide repertoire of schemata. ${ }^{2}$ This

1. The film L'arrivée d'un train à la Ciotat was first screened in october 10th, 1897 at Lyon under the title Arrivée d'un train à la Ciotat. There was no arrival of a train screened in 1895. The first screening of an arrival of a train was on January 25th, 1896 at Lyon, but under the title L'arrivée en gare d'un chemin de fer. This was not the film L'arrivée d'un train $\grave{a}$ La Ciotat because one of the little girls walking on the platform of the station is Madeleine Koehler, a niece of Louis Lumière, that was born in june 1st, 1895. Source: Institut Lumière, Mr. Jean-Marc Lamotte.

2. Schemata: an arrangement of knowledge already possessed by the perceiver used to predict and classify new sensory data. Cf. David Bordwell (2008: 31) e Francesco Casetti (1994: 124-125). 
means that audiences had to learn how to interpret the content of a two dimensional technical visual representation into a three dimensional historical world.

Robert Flaherty, in an interview about the making of his film Nanook of the North (1922), explained that Inuit culture could not comprehend the content of a still photograph. The Inuit could not relate the world they inhabited to the photograph's two dimensional visual representation for they had never seen a photograph beforehand. According to Flaherty they had to learn how to interpret the two dimensional representation of a three dimensional historical world. Once they had understood the connection between the technical format and the world that was familiar to them they were able to deduce subsequent representations accordingly. Flaherty, argued, that the same applied to moving images (Flaherty, 1996).

As we know, films are made up of a series of individual images called frames. When these images are shown rapidly in succession, a viewer has the illusion that motion is occurring. The viewer cannot see the flickering between the frames. Cinema's illusion takes advantage of two deficiencies in our visual system. First, the retina is unable to adjust rapidly to changing light intensities. Second, the phenomenon known as apparent motion occurs when the eye sees a string of displays as a single moving one. Therefore, despite the fact that celluloid film comprises of still photographic images, when projected at a certain speed, they produce the illusion of moving images. This means that cinema presents a greater complexity in terms of interpretation and understanding than a still photograph. In fact, in order to watch and understand cinema we have to draw on schemata derived from our experiences with the world, with other art forms such as photographs, painting, theatre or novels and, of course, with other films. Seeing and therefore watching films, is not a passive absorption of stimuli. It is a constructive activity, involving very fast computations, stored concepts, and various purposes, expectations, and hypotheses (Bordwell, 2008: 31-32; Plantinga, 1997: 54-58; Casetti, 1994: 114-115; Villafañe, 1987:30-36 e 68-71).

Francesco Casetti argues that cinema is also, like painting, a language medium, through which we create and express meaning. Therefore, cinema is also an act of communication and a means for the exchange of information (Casetti, 1994: 67). But in order to communicate the spectator needs to understand how this complex medium produces meaning and represents the world we live in. Therefore, how is it possible that Lumière's audience experienced cinema as if it was reality? 
George Méliès, a magician who became into a famous filmmaker, offered a poignant explanation. He resorted to three Lumière films to support his arguments. In the film Le repas de bébé, Auguste Lumière and his wife appear feeding their baby. Méliès claimed that the audience was not overwhelmed by the moving figures themselves, but by the rustling foliage in the background plane of the composition. Moreover, in the film A boat leaving a harbour, it was the random movement of the waves which attracted the public's attention, and in Demolishing a wall, it was the floating dust. Méliès argued that audiences, at the time, were already prepared to receive illusions performed on a theatre stage and so they could easily accept cinema as another sort of trickery. Méliès himself was an experienced magician accustomed to performing magic tricks on a stage in front of an audience and so he understood the spectator's ability to accept illusion. However, brick dust, random waves or rustling leaves were overpowering since they offered evidence of an event's past existence. Thus, Lumière's films were not just another illusion but a direct reflection of a past reality (Cousins \& MacDonald, 1996: 4).

Those details served as evidence to the audience that the image content referred to a past reality for they had confirmed one of the most essential features of the visible world that we inhabit: movement. This is why, Bazin and Tarkovsky had argued that cinema, unlike painting or any previous art forms ever seen before, appears to be able to represent reality as we see it (Bazin, 1971: 11-13). Film becomes the most "realistic art" in respect to the fact that it is precisely on its identification with reality that differentiates cinema from other art forms (Tarkovski, 1990: 18-19).

It is particularly fascinating to watch Lumière's films even today. Filmmakers, students, and university lecturers still find it fascinating to see how life looked in the 1890s whether it's the streets, the buildings, the trams, clothing, people walking or solely the way Paris, Peking and Piccadilly were in those days (Rollyson, 2006: 8-14). Like Gorky had claimed, they present silent grey ghosts, shadows of the past for they are all dead and much of what we see in their films no longer exists.

Nevertheless, these two dimensional images offer evidence of their past three dimensional existence. Like Bill Nichols states: "film offers by itself a tangible "memory theatre" of the past: an external visible representation of what was said and done" (Nichols, 2001: 58).

Hence, Lumière's films confirmed through visual representation evidence of a past existence in the historical world. For this reason we can argue that it is first through documentary that cinema is revealed to the world. Nevertheless, Lumière's films were also the result of a technically staged reality (Barnouw, 
1993: 21-22). People in their films responded to signals coming from behind the camera. The subjects involved in L'arrivée d'un train à la Ciotat were members of the Lumière family and not anonymous people arriving to a train platform. They followed cues and directions and they performed rehearsals so as to achieve the correct camera position (Cousins \& MacDonald, 1996: 5).

From the very birth of cinema we learned that we had to tamper with the medium in order to represent reality. The Lumière brothers were forced to stage their films due to technical restrictions such as depth of field, film-stock sensitivity, focal distance or aperture. Conversely, film offered great possibilities of technical manipulation and filmmakers quickly started experimenting and exploring its creative potential.

Soon after Lumière's invention, filmmakers, such as Georges Méliès learned to exploit and explore the technical possibilities of the medium. Méliès made a masterful use of double exposures, masks, lenses, camera angles, dissolves or fades to create his magical and overwhelming cinematic effects. In his famous film Le voyage dans la lune (1902) characters appear suddenly on the frame from scratch and grow in size tremendously in front of the astonished spectator's eyes. As early as 1898, British producer James Williamson filmed Attack on a chinese mission in his back yard shooting some of his Boer War scenes on a golf course. This new medium opened a new door of infinite creative possibilities where everything seemed possible, and in just a few years, fakes and reconstitutions became a very popular genre. By 1900 fiction films, and not documentaries, dominated audience's attention and acquired most of the market.

Conversely, Lumière's actualités became a repetitive formula loosing their initial popularity and failing to engage public attention. The Lumière brothers had began making fascinating reflections on French middle class life. However, their camera operators, who travelled from Europe as far as to Japan or India, across the world, began making films about Kings, Tsars, Kaisers, Emperors, Maharajahs and became some kind of agents of imperial public relations far from the social contents that had primarily thrilled their viewers (Barnouw, 1993: 21-25). As a result, Lumière's films lost their public appeal and popularity since the authenticity and originality of their actualités became a repetitive marketing formula that failed to surprise and engage public interest.

It is Robert Flaherty that managed successfully to synthesise the captivating authenticity of actualités and the dramatic engaging procedure of fiction films (Cousins \& MacDonald, 1996: 18-19). After serious distribution and exhibition difficulties in 1922 Flaherty presented Nanook of the North at the Capitol theatre in New York. Soon after the film became a complete internati- 
onal success and it became a landmark in film making until today. Nanook of the North is a film shot on location, with non-actors, about the Inuit way of life, stylistically a precursor of one of the most influential cinematic movements in film history: the later Italian Neorealism. (Sherwood, 1979:17-19).

In this film Flaherty decided to document past traditional ways of Inuit life. For that purpose he consciously omitted all references that could reveal their present culture at the time of filming. He asked Allakarialak, the protagonist, to re-enact his father's generation's experience and not his own contemporary Inuit lifestyle (Winston, 2005: 188). At the time Allakarialak did not hunt anymore with a harpoon but he used instead a rifle. He also did not live anymore in an igloo as his father did in the past. However, Flaherty chose to represent Allakarialak as if he actually did (Barnouw, 1993: 32).

In fact, Flaherty, at the time, due to technical reasons, was unable to film inside a real igloo. This was due to the fact that lighting conditions did not allow it. It was too dark and the film stock used at the time could not expose the image correctly. Consequently, he asked Allakarialak to construct a half oversized igloo which he used as background composition (Nichols, 2001: $85)$.

This way Flaherty could film the characters as if in fact they were living inside a real igloo. He was able to achieve this through careful shot composition. He knew that by selecting a closer focal distance he could frame the igloo and the characters in one shot without revealing that the igloo was a fake. It was a question of technically omitting the surrounding area of the igloo from appearing in the frame. This way he was able to create the technical appearance that Allakarialak and his family lived inside a real igloo.

Conversely, the family members of Nanook of the North are not related. They are not a real family. They were chosen by Flaherty to represent what he considered to be an ideal Inuit family. This is a practice that he repeated in Man of Aran (1934) and Louisiana story (1948) in order to represent what he considered to correspond to an ideal Irish or Cajun family (Ruby, 2005: 215).

Flaherty's masterful practice demonstrates his knowledge and awareness of cinema's technical restrictions and creative possibilities for representing the historical world. On the one hand, he was not able to film inside a real igloo: this illustrates a specific technical restriction. On the other, he was able to overcome this constraint, via composition. This also exemplifies the medium's technical capabilities for representing the world. In fact, Flaherty was successful on representing traditional ways of living which no longer existed. $\mathrm{He}$ managed to do so, because cinema's technical characteristics, offered him the opportunity to omit all visual and sound information which could discredit his 
representation. Thus, cinema allowed Flaherty to omit technically all evidence of present Inuit lifestyle in order to represent the past.

On the other hand, like Dziga Vertov points out on his "Kino-Pravda" (film-truth) writings cinema's technical qualities provide us with infinite creative possibilities to represent and learn about the world we inhabit. It can help us to perceive and comprehend numerous aspects about our existence in ways which we could not just achieve through our own senses. For Vertov the camera in combination with editing, which he called "Kino-eye" (that which the eye does not see) was superior to the human eye, since cinema, through its technical capabilities, could reveal a deeper level of "truth" about the world which normally would not be perceivable to the human eye (Vertov, 1984: 8592).

There is a fundamental difference between that which is humanly visible and that which is technically visible through the camera "eye". On the one hand, we have to admit that a camera can present a subject in ways we could never achieve through our eyes. We could use a macro lens to film the eyes of a very small spider or we could slow down the movement of an action and reveal details about the movement which are not perceptible by eyesight.

On the other hand, cinema through filming and editing allow us to explore subjects and events creatively by expressing our personal viewpoints. This provides a medium for learning and exploring our understanding and knowledge of the world in a way which we could not accomplish just through our own experience.

However, Flaherty's successful results in representing a past which does not exist anymore may also raises issues regarding the "truth" or authenticity of the event represented and therefore, we could argue against cinema's ability to represent reality. When we watch Nanook of the North we cannot help but feel that these images breathe truthfulness and authenticity. Flaherty's staged representation seems strikingly real. This is due to the technical appearance that his creative and technical treatment was able to accomplish. ${ }^{3}$ Flaherty, through cinema's technical qualities, managed to convince us of the authenticity of his representation. This seems to suggest that representing an event through cinema it is not just a question of the source authenticity but also of the technical appearance we are able to create to satisfy the spectator's expectations.

In Haskell Wexler's declarations in an interview about his documentary Brazil: A report on torture, (1971) similar "representations" are brought into

3. Peter Wintonick on his documentary Cinéma Vérité, defining the moment (1999) interviewed Jean Rouch and asked him about his experience of watching Flaherty's Nanook of the North. Rouch claimed that he saw the film when he was a child. He was very impressed and asked his father if the story was real. Rouch's father answered that it was "real" but it had been "represented" in front of the camera. 
question. Wexler explained that before editing his film he showed the rushes to some friends. One of his friends immediately pointed out that one of the testimonies did not seem sincere. Even though Wexler knew that the character was telling the "truth" he was also aware that his friend was right. The way the camera had captured the testimony and therefore, the way cinema had technically represented that real event, did not seem technically authentic. The posture of the testimony, the facial expression, the sound of the voice, the chosen focal length for the shot, the angle, the lightning set-up, or the background in the composition were all elements, amongst many others, that combined resulted in the representation of the event. All these elements convey information about the event. However, something in that chosen combination by the filmmaker was not technically appropriate for representing it. This suggests that one or more of those elements may have signified event information which undermined the credibility of the testimony. This resulted on questioning its authenticity (Wexler, 1996: 298).

Haskell Wexler's Brazil: A report on torture is a case of a documentary with real people talking about their experiences of being tortured: real traumatic and tragic life experiences. However, Wexler and his friends were forced to evaluate the content of the rushes in terms of what they appear to represent technically and not in terms of the source authenticity at the time of filming. The same applied to Lumière's films, perhaps in a more unconscious way. However, they were also forced or simply intuitively felt that they had to stage and give directions to represent their vision of what a train arriving at a platform was like at the time. Filming and pointing the camera was not enough. Not even for a one-minute film with no cuts.

The fact is that representing reality through cinema involves a number of unavoidable complex technical procedures and choices such us aperture, lighting, focusing, focal distance or camera movement. These choices, amongst many others, mean to transform event information from a three dimensional historical world into a two dimensional visual format. This as a result may raise issues regarding the credibility or authenticity of the technical appearance of the event represented.

This is why Seymour Chatman argues that achieving technical verisimilitude is not just a question of what it is "real" but also of what it is "ideal" (Chatman, 1978: 48-51). Thus, representing is not just a question of what an event is but also of what the event should appear to be. This implies that the credibility of the technical appearance of the event represented depends partly on satisfying the audience's expectations which suggests that in order for an event to appear technically credible it must also satisfy certain cultural ex- 
pectations. Chatman's arguments pinpoint that in different cultures there are different expectations, guidelines or references about what can be acceptable as technically credible or authentic. An event might appear to be technically believable in a European culture, however, in an Asian culture it may be the opposite. Hence, Haskell Wexler's credibility issues with regard to his testimony might only be applicable to his own culture. In other countries the same creditability issues may not arise or it may be that other issues become apparent. Therefore, the technical "authenticity" of representation varies in accordance to the cultural expectations where the film appears publicly presented.

From the very beginning of cinema's creation we learned that representing reality, due to its technical restrictions, it always involved some form of staging. Simply by choosing a camera position and composition or by setting a particular focal distance and aperture we are already technically staging the representation of reality. It is technically unavoidable. This is why the same technical qualities that allow Flaherty to accomplish a credible staged reality or to Vertov to deepen our understanding of the world may also be the cause for Haskell's Wexler credibility issues. The same technical qualities may be source for restriction or creativity in representing the historical world since representing is not just the outcome of what the event "is" but also of what the event should "appear to be". And the convincing and seducing quality of the representation's appearance depends greatly on how reality has been technically staged to satisfy certain cultural expectations.

The creating potential of staging can also become a powerful mean to fabricate and distort reality in favour of ideologies and regimes in power. Masterful pre-war documentaries such as Leni Riefenstahl's Triumph des Willens (1934) and Olympia (1938) (Dargis, 1996: 130); Frank Capra's scripted series, Why we fight (1942-1945) (Barsam, 1992: 225-226), Lenin's film doctrine (Barnouw, 1993: 54) or John Grierson's contribution to the politicising of documentary (Barsam, 1992: 78-79), illustrates some examples of how cinema's staging of reality can influence people's opinions and attitudes towards a particular subject predisposing audiences' views and knowledge of the world. Cinema's ability to staged reality raises questions regarding the credibility of the images that we see and how, through cinema, we may form our opinions and knowledge of the world.

Through out history filmmakers have produced films that intend to raise our awareness towards that fact. Vertov in Man with the movie camera (1929) presents a cinematic reflection on the process by which the impression of reality is constructed. (Barnouw, 1993: 61; Barsam, 1992: 73-75). In his film, through a series of enacted scenes, he describes the process of filming and edi- 
ting and therefore the act of constructing a representation. Trinh Minh-ha in Reasssemblage (1982) questions cinema's ability to represent reality and the knowledge we may gather from a constructed representation. Luis Buñuel's Las hurdes (1933) questions and raises awareness of misrepresentations while Chris Marker's Sans soleil (1983) questions the assumptions of representing others in a politically, racially and culturally divided world (Nichols, 2001: 125-128).

\section{Bibliographic references}

Aitken, I. (1998). The documentary film movement: an anthology. Edinburgh: Edinburgh University Press.

Bazin, A. (1971). What is cinema?. Berkeley: University of California Press.

Bazin, A. (1971). The ontology of the photographic image. In A. Bazin, What is cinema? (pp. 11-13). Berkeley: University of California Press.

Barnouw, E. (1993). A History of non-fiction film. New York: Oxford University Press.

Barsam, M.R. (1992). Non-fiction film, a critical History. Revised and expanded edition, Indiana: Indiana University Press.

Bordwell, D. (1997). On the History of film style. Cambridge, Massachusetts and London: Harvard University Press.

Bordwell, D. (2008). Narration in fiction film. London and New York: Routledge.

Bordwell, D. \& Thompson, K. (2009). Film History: an introduction. New York: McGraw-Hill Higher Education.

Casetti, F. (1994). Teorías del cine. Traducción Pepa Linares, Madrid: Cátedra.

Chatman, S. (1978). Story and discours, narrative structure in fiction and film (pp. 48-51). New York: Cornell University Press.

Chatman, S. (1990). Coming to terms: the rhetoric of narrative in fiction and film. New York: Cornell University Press.

Cousins, M. \& Macdonald, K. (1996) (Ed.). Imagining reality, The Faber book of documentary. London: Faber and Faber Limited.

Danzker, J.-A.B. (1980). Robert Flaherty: photographer/filmmaker, The Inuit, 1910-1922. Vancouver: Vancouver Art Gallery. 
Dargis, M. (1996). Leni Riefenstahl, art and propaganda. In M. Cousins \& K. MacDonald (Ed.), Imagining reality, the Faber book of documentary (pp. 129-133). London: Faber and Faber Limited.

Ellis, J.C. \& McLane, B.A. (2005). A new History of documentary film. New York: Continuum.

Flaherty, R. (1996). Robert Flaherty talking. In M. Cousins \& K. MacDonald (Ed.), Imagining reality, the Faber book of documentary (pp. 36-42). London: Faber and Faber Limited.

Gorky, M. (1996). The kingdom of shadows. In M. Cousins \& K. MacDonald (Ed.). Imagining reality, the Faber book of documentary (pp. 6-10). London: Faber and Faber Limited. [A review of the Lumière programme at the Nizhni-Novgorod Fair, as printed in the "Nizhegorodski listok "newspaper, 4 July I896, and signed "I.M. Pacatus" a pseudonym for Maxim Gorky].

Grant, K.; Jeannette, B. \& Sloniowski (1998). Documenting the documentary: close readings of documentary film and video. Detroit, Michigan: Wyane State University Press.

Hardy, F. (Ed.) (1966). Grierson on documentary. Revisited edition, Los Angeles: University of California Press.

Jacobs, L. (1979). The military experience and after. In L. Jacobs (Ed.), The documentary tradition (pp.182-189). New York: W. W. Norton and Company, Inc.

Keith, B. (Ed.) (1988). Documenting the documentary: close readings of documentary film and video. Michigan: Wayne State University Press.

Nichols, B. (1991). Representing reality: issues and concepts in documentary. Bloomington: Indiana University Press.

Nichols, B. (2001). Introduction to documentary. Bloomington: Indiana University Press.

Plantinga, C.R. (1997). Rhetoric and representation in nonfiction film. London: Cambridge University Press.

Rollyson, C. (2006). Documentary. Contexts and criticism. Lincoln: Universe Inc.

Rosenthal, A. \& Corner, J. (Ed.) (2005). New challenges for documentary. Manchester: Manchester University Press.

Ruby, J. (2005). The ethics of image making; or, they're going to put me in the movies. They're going to make a big star out of me.... In A. 
Rosenthal \& J. Corner (Ed.), New challenges for documentary (pp. 209220). Manchester: Manchester University Press.

Sherwood, R. (1979). Robert Flaherty's Nanook of the North. In L. Jacobs (Ed.), The documentary tradition (pp.15-20). New York: W. W. Norton and Company, Inc.

Tarkovski, A. (1990). Esculpir o tempo. São Paulo: Editora Martins Fontes.

Vertov, D. (1984). From Kino-Eye to Radio-Eye. In A. Michelson (Ed.), KinoEye: the writings of Dziga Vertov (pp. 85-92). Berkeley: University of California Press.

Villafañe, J. (1987). Introducción a la teoría de la imagen. Madrid: Ediciones Pirámide.

WexleR, H. (1996). From an interview in Take One, July-Aug 1971. In M. Cousins \& K. MacDonald (Ed.), Imagining reality, the Faber book of documentary (pp. 298-299). London: Faber and Faber Limited.

Winston, B. (2005). Ethichs. In A. Rosenthal \& J. Corner (Ed.). New challenges for documentary (pp.181-194). Manchester: Manchester University Press.

\section{Filmography}

Las Hurdes (1932), by Luis Buñuel.

Why we fight (1942-1945), by Frank Capra.

Man of Aran (1934) Robert Flaherty.

Sans soleil (1983), by Chris Marker.

A trip to the moon / Le voyage dans la lune (1902), George Méliès.

Reassemblage: from the firelight to the screen (1983), by Trinh Minh-ha.

L'arrivée d'un train à la Ciotat (1895), by Auguste and Louis Lumière.

Triumph des willens (1935), by Leni Riefenstahl.

Olympia, (1938), by Leni Riefenstahl.

Man with the movie camera, (1929) by Dziga Vertov. 